DOI: 10.46340/eppd.2020.7.5.13

Yevhenii Shylo

ORCID ID: https://orcid.org/0000-0002-2778-3602

V.M. Koretsky Institute of State and Law of the National Academy of Sciences

of Ukraine, Kyiv

\title{
PLANNING FUNCTION OF THE NATIONAL POLICE OF UKRAINE: PROBLEMS OF LEGAL SUPPORT AND DIRECTIONS FOR IMPROVING
}

\author{
Євгеній Шило \\ Інститут держави і права ім. В.М. Корецького НАН України, м. Київ \\ ФУНКЦІЯ ПЛАНУВАННЯ НАЦІОНАЛЬНОЇ ПОЛІЦЇ̈ \\ УКРАЇНИ: ПРОБЛЕМИ ПРАВОВОГО ЗАБЕЗПЕЧЕННЯ \\ ТА ШЛЯХИ УДОСКОНАЛЕННЯ
}

The article deals with scientific views on the concepts of management function and planning function. Legal acts regulating the performance of the planning function by the National Police of Ukraine are studied. The interrelationship between planning function and the powers of the National Police of Ukraine, their legal support is studied. The police units that perform the planning function and the powers they are given to perform this function are identified. The British experience of legal regulation of the planning function is being researched. Based on the analysis, the author proposes directions for improving the organizational and legal support of the National Police of Ukraine as a central executive body by introducing amendments to certain legislative acts of Ukraine.

Keywords: National Police of Ukraine, central executive body, powers and authority, planning, legal support.

Вступ. Одним із результатів розвитку державно-управлінських відносин в Україні стало створення нового центрального органу виконавчої влади- Національної поліції України. Від результативності його роботи залежить публічна безпека і порядок, захист прав та інтересів людини. Функції та повноваження Національної поліції України є ключовими елементами, за допомогою яких досягається такий результат, який прагне отримати влада і суспільство від створення та діяльності відповідного державного органу.

На даний час, спостерігається проблеми з неналежним нормативно-правовим забезпеченням функції планування Національної поліції України, що створює проблеми з ефективністю ії виконання. У зв'язку з цим актуальним для розвитку організаційно-правового забезпечення діяльності Національної поліції України, як центрального органу виконавчої влади, є вдосконалення правового забезпечення функції планування та повноважень, за допомогою яких вона здійснюється. Дієвим способом досягнення такої мети $є$ аналіз діючих нормативно-правових актів України, вивчення зарубіжного досвіду та надання обгрунтованих пропозицій змін до законодавства.

Стан дослідження. Окремі аспекти питання правового забезпечення функцій Національної поліції України висвітлювались у працях О.А. Банчука, К.Л. Бугайчука, Д.С. Денисюка, О.Ф. Кобзаря, Д.М. Ластовича, О.Ю. Салманової, О.С. Проневича та інших. Незважаючи на наявні наукові дослідження, проблема правового забезпечення функції планування Національної поліції України $є$ недостатньо висвітленою і потребує додаткового вивчення.

Мета дослідження полягає у тому, щоб на основі аналізу існуючих наукових підходів, вітчизняного і зарубіжного досвіду правового забезпечення функції планування діяльності поліції запропонувати шляхи удосконалення нормативно-правового забезпечення функції планування Національної поліції України як центрального органу виконавчої влади. 
Виклад основного матеріалу. Національна поліція України, як центральний орган виконавчої влади, виконує управлінські функції. В.Б. Авер'янов зазначив, що функції органів виконавчої влади повинні розглядатися як функції управлінської діяльності (або управління). Їх слід розуміти, як відносно самостійні та якісно однорідні складові діяльності цих органів, які характеризуються цільовою спрямованістю. Подібного підходу притримується Ю.П. Битяк, який зазначає, що функції управління, як поняття, - це певний напрям спеціалізованої діяльності виконавчої влади, зміст якої характеризується однорідністю та цільовою спрямованістю.

Національна поліція України, як центральний орган виконавчої влади, виконує функції внутрішньо-організаційного характеру (спрямовані на управління апаратом та територіальними органами) та зовнішнього характеру (відображають правоохоронне призначення поліції, направлені на об'єкти управління та реалізуються через спеціальні повноваження).

Однією з внутрішньо-організаційних функцій управління Національної поліції України $є$ планування. Ця функція $є$ стрижневою частиною усіх систем управління, процес, за допомогою якого система пристосовує свої ресурси до зміни зовнішніх і внутрішніх умов. Відповідно до Енциклопедії державного управління під поняттям «функція планування» слід розуміти визначення напрямів, темпів, кількісних і якісних показників тих чи інших процесів у системі державного управління, державних функцій, спрямованих на досягнення попередньо визначених цілей; розробку цілей і завдань, напрямі розвитку та реформування усієї державно-управлінської діяльності. Планування за широкого тлумачення - це управлінська діяльність, яка інтегрує в собі функції цілепокладання, прогнозування, аналізу, прийняття рішень, які ще називають підфункціями планування. Прогнозування - це імовірнісна оцінка розвитку об'єкта управління у майбутньому, наукове передбачення, систематичне дослідження стану, структури, динаміки та перспектив управлінських явищ та процесів. Прогнозування досить часто передує плануванню, і здійснюється не тільки органами державного управління, але й науковими інститутами. В свою чергу цілепокладання полягає не тільки в розробленні основної, поточної і перспективної мети, а й у пошуку відповіді на запитання, як конкретно Національна поліція України буде домагатися реалізації поставленої мети.

О.Ф. Кобзар зазначає, що планування $є$ найважливішим мобілізуючим елементом, який дозволяє зосередити увагу і зусилля на найбільш актуальних проблемах громадського порядку, раціонально, збалансовано, адекватно розподілити наявні сили і засоби у вирішенні поставлених завдань, при скоординованій роботі забезпечити ритмічність і інтенсивність, відповідно, таким чином здійснюючи ефективне реагування. Загалом, говорячи про цю функцію слід зазначити, що надання відповідей на питання, що повинно бути зроблено? До якого терміну? Яким чином? Які ресурси для цього необхідні? Який очікуваний результат? Хто відповідальний? - є головним завдання функції планування.

У Національній поліції України організацією вирішення поставлених питань уповноважений займатися іiі керівник шляхом підписання правових актів управління та надання доручень своїм заступникам, начальникам структурних та територіальних підрозділів. Відповідно до п. 4, 9 ч. 4 ст. 19 Закону України «Про центральні органи виконавчої влади», пп. 5, 6 п. 11 Положення про Національну поліцію, затвердженого постановою Кабінету Міністрів України від 28.10.2015 р. № 877, керівник поліції подає на затвердження Міністрові внутрішніх справ України плани роботи свого відомства та звітує про їх виконання. Тобто він фактично підписує плани роботи, які подаються міністрові, та контролює їх виконання. Це ж стосується і керівників територіальних органів поліції на місцевому рівні, які відповідно до абз. 4, 6 п. 11 Типового положення про територіальні органи міністерства та іншого центрального органу виконавчої влади, затвердженого постановою Кабінету Міністрів України від 25 травня 2011 р. № 563, вносять міністру, керівнику центрального органу виконавчої влади пропозиції щодо визначення пріоритетів роботи територіального органу і шляхів виконання покладених на нього завдань та подають на затвердження плани роботи територіального органу (річні, піврічні), а також звітують про їх виконання.

Важливу роль у виконанні функції планування займають підрозділи організаційноаналітичного забезпечення та оперативного реагування, які діють на центральному рівні у складі апарату поліції та на регіональному рівні у складі головних управлінь в областях, Автономній Республіці Крим, м. Севастополі та м. Києві. Зокрема, в апараті діє Департамент організаційноаналітичного забезпечення та оперативного реагування. Його робота регламентується наказом Національної поліції України від 27.11.2015 № 126 про затвердження Положення про Департамент організаційно-аналітичного забезпечення та оперативного реагування Національної поліції України. 
В свою чергу, на рівні регіонів діють Управління організаційно-аналітичного забезпечення та оперативного реагування, які є структурними підрозділами головних управлінь. Їх утворення та діяльність врегульовано наказом Міністерства внутрішніх справ України 22.01.2016 № 39. Так, підрозділи організаційно-аналітичного забезпечення та оперативного реагування для виконання функції планування уповноважені:

- здійснювати збір, оцінку, аналіз інформації про криміногенну ситуацію, кримінальні правопорушення, порушення публічної безпеки і порядку, інші надзвичайні події та заходи реагування на них;

- організовувати комплексний аналіз стану охорони прав і свобод людини, інтересів суспільства і держави, протидії злочинності, а також надання поліцейських послуг;

- вивчати та аналізувати причини і умови, які негативно впливають на ефективність діяльності поліції та розробляти заходи щодо вдосконалення іiі діяльності;

- готувати комплексні аналітичні матеріали про стан оперативної обстановки в державі, проекти управлінських рішень щодо підвищення ефективності діяльності поліції з протидії злочинності та зміцнення правопорядку;

- виявляти, вивчати, узагальнювати й упроваджує в діяльність поліції передовий і позитивний досвід з питань управлінської діяльності. Брати участь в організації проведення наукових досліджень у цьому напрямі;

- організовувати і здійснювати поточне й перспективне планування, розроблення планів основних організаційних заходів поліції;

- складати звіти про виконання запланованих заходів та покладених завдань, про усунення порушень і недоліків, виявлених під час проведення перевірок діяльності підрозділів поліції тощо.

Виходячи з вказаного, вбачається, що підрозділ організаційно-аналітичного забезпечення та оперативного реагування на чолі з їх керівниками здійснюють ключову аналітичну і виконавчу роль в реалізації функції планування, для чого їм надано широке коло повноважень.

Під час аналізу взаємозв'язку даної функції та повноважень, їх правового забезпечення, привертає до себе увагу те, що це питання регламентується виключно на рівні відомчих актів. Зокрема, ні Закон України «Про Національну поліцію», ні Положення про Національну поліцію, затверджене постановою Кабінету Міністрів України від 28.10.2015 p. № 877, не визначають видів планування, вимог до їх змісту, порядку підготовки та погодження планів, термінів, відповідальних осіб тощо. Ці питання частково врегульовуються лише на рівні наказів. Втім, для функції планування, як стрижневої частини системи управління, що забезпечує стабільність та прогнозованості роботи поліції, це є недопустимим з практичної і наукової точок зору.

Таким чином, більшість положень про планування діяльності Національної поліції України як центрального органу виконавчої влади, закріплених в Законі України «Про Національну поліцію», $\epsilon$ доволі абстрактними і потребують детального регламентування з метою підвищення ефективності процесу планування та забезпечення стабільності і прогнозованості роботи цього органу влади.

Відзначимо, що в таких країнах сталої демократії як Нідерланди, Бельгія, Сполучене Королівство Великої Британії та Північної Ірландії, ці питання вже давно вирішуються на рівні спеціальних законів. Наприклад, в Англії та Уельсі діє Закон Сполученого Королівства про поліцію від 1996 року, який встановлює підготовку таких видів планів: трирічні стратегічні плани (розділ 6А); місцеві плани поліцейської діяльності (розділ 8); та Національний план поліцейської діяльності (розділ 36А). Перший та другий види планів видаються кожним органом поліції у відповідних поліцейських зонах Англії та Уельсу. Трирічні стратегічні плани визначають середньострокову і довгострокову стратегію поліцейської діяльності у відповідній поліцейській зоні протягом трирічного періоду часу (закон дозволяє визначати й інші строки його чинності) і видаються до початку такого періоду. В свою чергу, місцеві плани поліцейської діяльності видаються щорічно до початку кожного фінансового року (фінансовий рік означає період у дванадцять місяців, що закінчується 31 березня) і визначають порядок діяльності у зоні відповідного органу. До місцевого плану законом встановлюється ряд вимог, зокрема він повинен містити заяву про пріоритети поліцейської влади на даний рік, фінансові ресурси, виділення яких очікується, а також про пропозиції щодо розподілу таких ресурсів з докладним описом: усіх цілей поставлених Державним секретарем; усіх цілей визначених поліцейським органом; усіх цільових показників його роботи; та усіх дій, що пропонуються на виконання вимог по економічності, ефективності та результативності згідно Розділу I Закону про місцеве врядування від 1999 року. 
Крім строків прийняття, вимог до змісту, періоду дії трирічних і місцевих планів Закон Сполученого Королівства про поліцію від 1996 року встановлює порядок їх підготовки, погодження та відповідальних осіб. Так, перш ніж орган поліції видасть такі плани роботи, їх проекти мають бути підготовлені старшим офіцером сил поліції (старшим констеблем) та представлені на розгляд відповідному органу поліції. Відмітимо, що сам поліцейський орган може видати план відмінний від запропонованого старшим офіцером (старшим констеблем), але у такому випадку проводяться 3 ним консультації. У ході підготовки проекту плану старший офіцер сил поліції (старший констебль) або безпосередньо поліцейський орган повинен брати до уваги позицію населення. Також при підготовці трирічного стратегічного плану обов'язково береться до уваги діючий Національний план поліцейської діяльності, а при підготовці місцевого плану діючий трирічний стратегічний план у відповідній зоні. Всі ці документи повинні готуватися на підставі рекомендацій Державного секретаря (в нашому розумінні міністром). Зокрема, він визначає для органів поліції та для старших офіцерів поліції (старших констеблів) загальні настанови або керівні принципи стосовно питань, які повинні міститися у відповідному плані, а також стосовно формату такого плану. Вони є обов'язковими для прийняття до уваги та надаються після проведення консультацій з вказаними особами. Коли орган поліції видає трирічний стратегічний план та місцевий план діяльності, такий орган зобов'язаний: направити примірник плану до Державного секретаря, а також забезпечити його опублікування.

Стосовно Національного плану поліцейської діяльності, то за вищевказаним законом він готується до початку кожного фінансового року Державний секретарем та подається до Парламенту не пізніше 30 листопада попереднього фінансового року. До такого плану встановлюється ряд вимог за якими він повинен: визначатися всі позиції, які Державний секретар вважає стратегічними пріоритетами поліцейської діяльності взагалі для сил поліції, на період у три роки; міститися опис того, що планує або пропонує Державний секретар за кожним з наступних напрямків: визначення завдань і надання загальних вказівок стосовно кожного з таких завдань; визначення показників якості роботи для органів поліції; видання нормативних положень відповідно до наданих повноважень; видання керівних настанов; видання та перегляд кодексів поведінки тощо. Перш ніж подавати Національний план поліцейської діяльності на фінансовий рік до Парламенту, Державний секретар повинен провести консультації з:- особами, які, на його думку, представляють інтереси органів поліції; - особами, які, на його думку, представляють інтереси старших офіцерів поліції; - іншими особами на його власний розсуд.

Таким чином, порядок складання та реалізації планів поліцейської діяльності в Англії та Уельсі доволі грунтовно врегульований на законодавчому рівні та має ряд особливостей. Так, першою суттєвою особливістю $є$ чітке визначення видів планів, їх змісту, сфери регулювання та взаємопов'язаності. Другою особливістю є самостійність поліцейського органу у прийнятті кінцевого рішення по відповідному плану. Третьою особливістю є залучення широкого кола зацікавлених осіб до розробки планів, що дозволяє врахувати позицію працівників поліції, представників центральної влади та населення.

Відмітимо, що в чинному законодавстві України жодна з цих особливостей не врахована. В Україні навпаки, повноваження стосовно остаточного затвердження планів та звітів діяльності Національної поліції України належить не голові, а Міністру внутрішніх справ України. Аналогічно з повноваженням місцевої громади, яка відсторонена від цього процесу. Це при тому, що поліція $є$ окремим центральним органом виконавчої влади, який не входить до структури вказаного міністерства.

Отже, на основі проведеного аналізу, вважаємо, що для підвищення ефективності планування в Національній поліції України, стабільності і прогнозованості роботи цього центрального органу виконавчої влади, слід використати британський досвід детального правового регламентування цього питання у спеціальному законі та врахувати ключові особливості складання та реалізації планів. Відмітимо, що більшість положень чинного Закону України «Про Національну поліцію» є доволі абстрактними і занадто гнучкими. У зв'язку з цим, пропонуємо доповнити Закон України «Про Національну поліцію» окремим розділом під назвою «Планування поліцейської діяльності», який має визначати ключові моменти щодо: видів планування; вимог до змісту планів; термінів їх підготовки та строків дії; відповідальних осіб та їх повноважень; порядку підготовки, погодження, видання, зміни та реалізації планів і звітів про їх виконання. 


\section{References:}

1. Averianov, V. B. (2007). Administratyvne pravo Ukrainy. Akademichnyi kurs. Zahalna chastyna [Administrative law of Ukraine. Academic course. The general part]. Kyiv: Vydavnytstvo «Iurydychna dumka», 1, 592. [in Ukrainian].

2. Harashchuk, V.M. Bohutskyi, V.V. (2010). Administratyvne pravo [Administrative law]. Kharkiv: Pravo. [in Ukrainian].

3. Bilokur, Ye.I. (2015). Funktsii derzhavnoho upravlinnia: poniattia, osoblyvosti, pravove rehuliuvannia [Functions of public administration: concepts, features, legal regulation]: dysertatsiia na zdobuttia naukovoho stupenia kandydata yurydychnykh nauk [dissertation for the degree of candidate of legal sciences]. Odesa. [in Ukrainian].

4. Kovbasiuk, Yu.V. (2011). Entsyklopediia derzhavnoho upravlinnia u 8 tomakh. Teoriia derzhavnoho upravlinnia. [Encyclopedia of Public Administration in 8 volumes. Theory of public administration]. Kyiv: Natsionalna akademiia derzhavnoho upravlinnia pry Prezydentovi Ukrainy, 1, 748. [in Ukrainian].

5. Hordon, M.V. (2013). Derzhavnyi menedzhment v konteksti administratyvnoi reformy: navchalno-metodychnyi posibnyk [Public management in the context of administrative reform: a textbook]. Donetsk: DOTsPPK. [in Ukrainian].

6. Kobzar, O.F. (2016). Administratyvno-pravove rehuliuvannia politseiskoi diialnosti v Ukraini [Administrative and legal regulation of police activity in Ukraine]: dysertatsiia na zdobuttia naukovoho stupenia doktora yurydychnykh nauk [dissertation for the degree of Doctor of Law]. Dnipropetrovsk. [in Ukrainian].

7. Zakon pro tsentralni orhany vykonavchoi vlady 2011 ) [Law on Central Executive Bodies 2011] (Verkhovna Rada Ukrainy [(Verkhovna Rada of Ukraine)]. Ofitsiinyi sait Verkhovnoi Rady Ukrainy [The official website of the Verkhovna Rada of Ukraine]. <http://zakon2.rada.gov.ua/laws/show/3166-17/print1443105964459820> (2020, March, 28). [in Ukrainian].

8. Postanova pro zatverdzhennia Polozhennia pro Natsionalnu politsiiu 2015 [Resolution on approval of the Regulation on the National Police 2015] (Kabinet Ministriv Ukrainy) [(Cabinet of Ministers of Ukraine)]. Ofitsiinyi sait Verkhovnoi Rady Ukrainy [The official website of the Verkhovna Rada of Ukraine]. <http://zakon3.rada.gov.ua/laws/show/877-2015-\%D0\%BF> (2020, May, 19). [in Ukrainian].

9. Postanova pro zatverdzhennia Typovoho polozhennia pro terytorialni orhany ministerstva ta inshoho tsentralnoho orhanu vykonavchoi vlady 2011 [Resolution on approval of the Standard Regulations on territorial bodies of the Ministry and other central executive body 2011] (Kabinet Ministriv Ukrainy) [(Cabinet of Ministers of Ukraine)]. Ofitsiinyi sait Verkhovnoi Rady Ukrainy [The official website of the Verkhovna Rada of Ukraine]. <https://zakon.rada.gov.ua/laws/show/563-2011-\%D0\%BF> (2020, February, 14). [in Ukrainian].

10. Nakaz pro zatverdzhennia Polozhennia pro Departament orhanizatsiino-analitychnoho zabezpechennia ta operatyvnoho reahuvannia Natsionalnoi politsii Ukrainy 2015 [The order approving the Regulation on the Department of Organizational and Analytical Support and Operational Response of the National Police of Ukraine 2015] (Natsionalna politsiia Ukrainy) [(National Police of Ukraine)]. Ofitsiinyi sait Natsionalnoi politsii Ukrainy (stara versiia) [The official website of the National Police of Ukraine (old version)]. <https://www.npu.gov.ua/uk/publish/article/1815135> (2017, December, 25). [in Ukrainian].

11. Nakaz pro zatverdzhennia Typovoho polozhennia pro upravlinnia orhanizatsiino-analitychnoho zabezpechennia ta operatyvnoho reahuvannia holovnykh upravlin Natsionalnoi politsii Ukrainy v Avtonomnii Respublitsi Krym ta m. Sevastopoli, oblastiakh, m. Kyievi 2016[Order on approval of the Standard Regulations on the Department of Organizational and Analytical Support and Operational Response of the Main Departments of the National Police of Ukraine in the Autonomous Republic of Crimea and Sevastopol, oblasts, Kyiv 2016] (Ministerstvo vnutrishnikh sprav Ukrainy) [(Ministry of Internal Affairs of Ukraine)]. Ofitsiinyi sait Verkhovnoi Rady Ukrainy [The official website of the Verkhovna Rada of Ukraine]. 〈http://zakon3.rada.gov.ua/laws/show/z0216-16〉 (2020, September, 09). [in Ukrainian].

12. Zakon pro Natsionalnu politsiiu 2015 [Law on the National Police 2015] (Verkhovna Rada Ukrainy) [ (Verkhovna Rada of Ukraine)]. Ofitsiinyi sait Verkhovnoi Rady Ukrainy [The official website of the Verkhovna Rada of Ukraine]. <http://zakon3.rada.gov.ua/laws/show/580-19> (2020, September, 11). [in Ukrainian].

13. Police Act 1996 (UK Parliament). The official website of United Kingdom legislation. <https://www.legislation.gov.uk/ukpga/1996/16/contents> (2018, January, 09). [in English].

14. Banchuk, O.A. (2013). Status politsii: mizhnarodni standarty i zarubizhne zakonodavstvo [Police status: international standards and foreign legislation]. Kyiv: Moskalenko O.M. [in Ukrainian]. 